\title{
Identification of Chemical Content and Antihypertensive Activity Test of Ethanol Extract from Tali Bamboo Shoot (Gigantochloa apus (Schult. \& Schult.F.))
}

\author{
$1^{\text {st }}$ Sunarti \\ Department of Pharmacology and Clinical Pharmacy \\ Harapan Bangsa University \\ Purwokerto, Indonesia \\ sunarti@uhb.ac.id
}

\author{
$2^{\text {nd }}$ Peppy Octaviani \\ Department of Clinical Pharmacy \\ Harapan Bangsa University \\ Purwokerto, Indonesia \\ octaviany.peppy@gmail.com
}

\begin{abstract}
Tali bamboo shoot is young shoot of bamboo potential to treat several diseases, one of them is hypertension. The aim of this study was to qualitatively identify chemical compounds and to determine antihypertensive activity of Tali bamboo ethanol extract. Extraction method applied in this experiment was maceration using ethanol 70 percent solvent. Qualitative identification toward Tali bamboo shoot powder and extract conducted using chemical reactor. Antihypertensive examination used male white rats Sprague-Dawley divided into 5 groups 5 rats each. Group I negative control (CMC Na 1percent), group II: positive control (Hydrochlorothiazide), Group III: Tali bamboo ethanol extract dose $40 \mathrm{mg} / \mathrm{Kg}$ rat body weight, Group IV: dose $80 \mathrm{mg} / \mathrm{Kg}$ rat body weight, and group V: dose $160 \mathrm{mg} / \mathrm{Kg}$ rat body weight. The results of study indicate that Tali bamboo shoot powder and ethanol extract contain flavonoid, phenolic, saponins and tannins. Tali bamboo shoot ethanol extract indicated decrease of systolic blood pressure activity in male white rats SpragueDawley at dose of $40 \mathrm{mg} / \mathrm{Kg}$ rat body weight, $80 \mathrm{mg} / \mathrm{Kg}$ rat body weight dan rat $160 \mathrm{mg} / \mathrm{Kg}$ body weight.
\end{abstract}

Keywords: tali bamboo shoot, chemical compounds, antihypertensive

\section{INTRODUCTION}

Tali bamboo shoot is a plant that grows in Indonesia. It can grow in various places both in the lowlands and highlands, in very dry or humid areas, and in areas that are inundated with water for 2-3 months[1]. Tali bamboo (Gigantochloaapus) is a type of bamboo with sympodial, tight, and upright clumps. Many communities in Java and Bali have planted bamboo ropes[2].

The benefits of tali bamboo shoot as the main nutrients that are important for the body such as protein, carbohydrates, amino acids, minerals, fat, sugar, fiber, and inorganic salt. Tali bamboo shoot have a good mineral profile, consisting mainly of potassium, calcium, manganese, zinc, chromium, copper, iron, plus a lower amount of phosphorus and selenium. Bamboo shoot are a good source of thiamine, niacin, vitamin A, vitamin B6 and vitamin E. It contains 17 amino acids, 8 of which are essential for the human body, containing 57-67percent tyrosine from the total amino acid content. The fat content is relatively low (0.26-0.94percent) and contains essential fatty acids. Total sugar content, 2.5 percent on average, is lower than other vegetables. The water content is 90 percent or more [3], [4].

The use of tali bamboo shoots as a medicinal ingredient is not widely known by the public, because clinically the dosage and chemical compounds are unknown. Tali bamboo shoots are thought to have immunomodulatory, anti-tumor, anti-inflammatory, and antioxidant properties. Some bamboo research has produced information about chemical compounds, but systematic evaluation has not been carried out and is not specific to the type of bamboo studied, including plant parts and chemical compounds that might function as medicine. Uncovering research about the use of bamboo rope bamboo shoots in the world of medicine is still small when compared with other types of plants [5], [6]. The purpose of this study was to determine the content of chemical compounds and the effects of tali bamboo shoot extract as an antihypertensive agent so that it could be used for herbal medicine. 


\section{METHOD}

\section{Material}

The sample materials used in this study were $\mathrm{Mg}$ powder, concentrated $\mathrm{HCl}$, amyl alcohol, ethanol, Iron (III) chloride, hot water, $2 \mathrm{~N}$ hydrochloric acid, distilled water, tali bamboo shoot, prednisone, $\mathrm{NaCl} 150 \mathrm{mg} / \mathrm{kgBW}$, $\mathrm{FeCl} 3$, hidroklortiazid, $\mathrm{CMC} \mathrm{Na} 1^{\circ}$ percent, white male Sprague-Dawley strain rats aged 2-3 months and weighing 150-300 grams.

\section{Tool}

The tools used were reaction tubes, beaker glass, volume pipettes, stirring rods, measuring cups, $100 \mathrm{ml}$ white bottles, dark glass bottles, blenders, 60 mesh size sieves, aluminum foil, filter paper, electric scales, Moisture Balance, mortars, stamper, oral sonde and Blood Pressure Analyzer (CODA).

Making the Powder of tali bamboo shoot

The simplicial used in this research is tali bamboo shoot taken in a fresh condition. Shoot that have been obtained are peeled, then washed to remove dirt and contamination. The next step is cut the bamboo shoot and dried in an oven at $40^{\circ} \mathrm{C}$ to dry. This drying aims to reduce the water content contained in bamboo shoot, thereby preventing the occurrence of enzymatic reactions that can reduce the quality and avoid the growth of fungi and bacteria. After dry bamboo shoots are blended using a blender, then sifted with a 60 mesh sieve size. Shoot that have been in the form of powder are weighed, then the results are put into a container and tightly closed which will be used for extracting[7].

\section{Making Extraction}

The tali bamboo root in powder form were weighed as much as $500 \mathrm{~g}$, then extracted by maceration method using 70 percent ethanol as much as $3750 \mathrm{ml}$ for 5 days with repeated stirring. Next maceration filtered using gauze and filter paper. Then the pulp is rinsed with the remaining $1250 \mathrm{ml}$ of solvent and left for 2 days. The filtrate from all samples is then evaporated using a device called a vacuum rotary evaporator.

\section{Identification of Chemical Content}

Flavonoid Test.

As much as $2 \mathrm{~g}$ of simplicia powder was added $20 \mathrm{ml}$ of hot water, boiled for 5 minutes and filtered under heat. The filtrate obtained was then taken $5 \mathrm{ml}$ and then added $0.1 \mathrm{~g}$ of $\mathrm{Mg}$ powder and $1 \mathrm{ml}$ of concentrated $\mathrm{HCl}$ and 2 $\mathrm{ml}$ of amyl alcohol, shaken and allowed to separate. If yellow, orange or red color is formed on the amyl alcohol layer, flavonoids show [8].
Phenolic test.

A total of 0.5 gram of sample was put into a test tube plus $2 \mathrm{ml}$ of ethanol, then the mixture was heated quickly. The mixture was cooled and filtered with filter paper. The filtrate was reacted with an iron (III) chloride reagent, said to be positive if a blackish purple color arise[8].

\section{Saponin Test}

$0.5 \mathrm{~g}$ of simplicia powder was put into a test tube, 10 $\mathrm{ml}$ of hot water was added, cooled and then shaken vigorously for 10 seconds. If a large froth is formed for not less than 10 minutes, as high as $1 \mathrm{~cm}$ to $10 \mathrm{~cm}$ and not disappear with the addition of 1 drop of $2 \mathrm{~N}$ hydrochloric acid indicates the presence of saponin[8].

\section{Tannin test}

A total of $1 \mathrm{~g}$ of simplicia powder is boiled for 3 minutes in $10 \mathrm{ml}$ of distilled water then cooled and filtered. Filtrate is diluted to almost colorless, then added $1-2$ drops of reagent iron (III) chloride, if there is a blackish blue or blackish green indicating the presence of tannin[8].

\section{Antihypertensive Activity Test}

Rats were grouped into 5 treatment groups:

Group I: Negative control (CMC Na 1 percent)

Group II: Positive control (Hydrochlorothiazide $0.09 \mathrm{mg} /$

$\mathrm{Kg} \mathrm{BW)}$

Group III: Tali bamboo shoot extract $80 \mathrm{mg} / \mathrm{kg} \mathrm{BW}$

Group IV: Extract of tali bamboo shoot $160 \mathrm{mg} / \mathrm{kg} \mathrm{BW}$

Group V: Tali bamboo shootextract of $320 \mathrm{mg} / \mathrm{kg} \mathrm{BW}$

Rats that have been weighed and grouped, then acclimated for 1 week at the study site to adjust to the environment. . Male white rats were placed in clean, wellventilated cages, 31 and were given a standard food and drink consumption for rats. After being acclimatized, rats were first fasted for 12 hours and their blood pressure was measured as initial blood pressure (T0), then they were induced with prednisone 0.01 percent with a volume of 3 $\mathrm{ml} / 200 \mathrm{~g} \mathrm{BW}$ and 1.5 percent $\mathrm{NaCl}$ with a volume of 2 $\mathrm{ml} / 200 \mathrm{~g} \mathrm{BW}$ orally for 21 days. Measuring rat blood pressure during induction of prednisone and $\mathrm{NaCl}$ on day 7 (T1), induction of day 14 (T2), induction of day 21 (T3), measurements were carried out at the rats (Nisa et al 2017; Nurjanah 2016). Then each group was given 1 percent CMC Na (negative control), hydrochlorothiazide (positive control) once a day, tali bamboo shoot extract $8 \mathrm{mg} / 200$ $\mathrm{g} \mathrm{BW}$ rats, $16 \mathrm{mg} / 200 \mathrm{~g} \mathrm{BB}$ rats and $32 \mathrm{mg} / 200 \mathrm{~g} \mathrm{BB}$ orally once a day for 21 days and followed by induction of 
prednisone and $\mathrm{NaCl}$ for therapy. Measuring rat blood pressure during therapy on day 28 (T4), day therapy 35th (T5), and 42nd day therapy (T6).

\section{RESULTS AND DISCUSSION}

The identification of tali bamboo shoot was carried out to determine the chemical content contained in the tali bamboo shoot. Based on the results of qualitative identification of the chemical content of tali bamboo shoot powder, it can be seen that it contains saponin and flavonoids. In addition, tali bamboo shoot powder is also known to contain polyphenols, tannin compounds precisely. The result was stated positive because there was a conformity between the observations and literature [6].

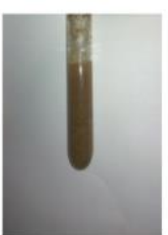

(a)

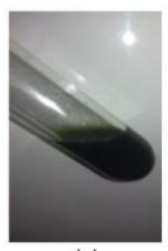

(e)

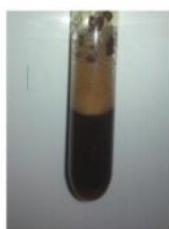

(b)

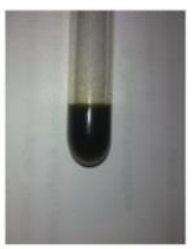

(f)

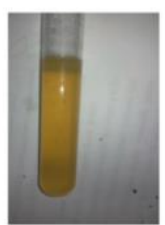

(c)

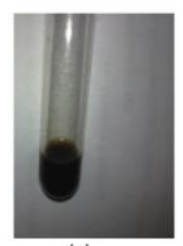

(g)
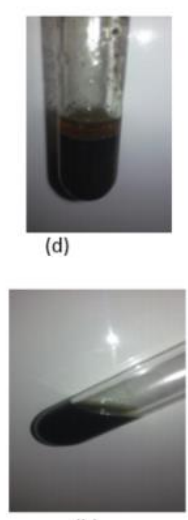

(h)
Note:

$$
\begin{array}{ll}
\text { A } & \text { : Saponin }+ \text { (powder }) \\
\text { b } & \text { : Saponin }+ \text { (extract })
\end{array}
$$

$$
\begin{array}{ll}
\mathrm{c} & \text { : Flavonoid }+ \text { (powder) } \\
\mathrm{d} & : \text { Flavonoid }+ \text { (Extract) } \\
\mathrm{e} & : \text { Fenolik }+ \text { (Powder) } \\
\mathrm{f} & : \text { Fenolik }+ \text { (Extract) } \\
\mathrm{g} & : \text { Tanin }+ \text { (Powder) } \\
\mathrm{h} & : \text { Tanin }+ \text { (Extract) }
\end{array}
$$

Activity of Antihypertensive

Antihypertensive activity test in this study uses the Tail Cuff method to measure systolic and diastolic blood pressure. This method is used to determine systolic and diastolic blood pressure. Prednisone and $\mathrm{NaCl}$ induction method is used to increase blood pressure in rats, because it will increase blood pressure significantly and constantly through the activation mechanism of Renin AngiotensinAldosterone System (RAAS) and fluid retention [9], [10]. The choice of hydrochlorothiazide as a positive control is because the mechanism of action of the drug is the same as the phytopharmaca material tested. The compounds in tali bamboo shoot that have biological activity as a diuretic are flavonoids. The mechanism of action of flavonoids as a diuretic is by inhibiting the reabsorption of $\mathrm{Na}+, \mathrm{K}+$ and $\mathrm{Cl}$ - resulting in an increase in the electrolyte in the tubules so that diuresis occurs. Hydrochlorothiazide works in the kidneys to increase the

\begin{tabular}{|c|c|c|c|c|c|c|c|c|c|c|c|c|c|c|}
\hline \multirow{2}{*}{$\begin{array}{l}\text { Treatment } \\
\text { Group }\end{array}$} & \multicolumn{2}{|c|}{$\mathrm{T} 0$ (mmHg) } & \multicolumn{2}{|c|}{$\mathrm{T} 1$ (mmHg) } & \multicolumn{2}{|c|}{$\mathrm{T} 2(\mathrm{mmHg})$} & \multicolumn{2}{|c|}{$\mathrm{T} 3(\mathrm{mmHg})$} & \multicolumn{2}{|c|}{$\mathrm{T} 4(\mathrm{mmHg})$} & \multicolumn{2}{|c|}{$\mathrm{T} 5(\mathrm{mmHg})$} & \multicolumn{2}{|c|}{$\mathrm{T} 6(\mathrm{mmHg})$} \\
\hline & Sistole & Diastole & Sistole & Diastole & Sistole & Diastole & Sistole & Diastole & Sistole & Diastole & Sistole & Diastole & Sistole & Diastole \\
\hline I & 111,4 & 79,6 & 126 & 83,2 & 127,8 & 92,2 & 140,2 & 104 & 150 & 106,8 & 154 & 115,6 & 161,2 & 121,8 \\
\hline II & 105,4 & 72 & 122 & 79,6 & 134 & 96 & 148,4 & 104,8 & 129,4 & 87,4 & 120,6 & 83,4 & 115 & 78,2 \\
\hline III & 102 & 67,4 & 126,2 & 83,6 & 134,2 & 87,2 & 142,4 & 105,8 & 139 & 92,8 & 133,4 & 92,4 & 129 & 89,8 \\
\hline IV & 99,4 & 71,2 & 126,4 & 85,6 & 134,8 & 90,2 & 142,2 & 107,8 & 140 & 100,4 & 137 & 97,2 & 136,4 & 94,8 \\
\hline $\mathrm{V}$ & 104 & 72,6 & 123 & 78,8 & 130,2 & 85,2 & 147,2 & 116,6 & 147 & 113,4 & 145 & 112,2 & 140,2 & 106 \\
\hline
\end{tabular}
excretion of water and sodium chloride. Most diuretics work by decreasing the reabsorption of electrolytes by the tubules. Increased electrolyte excretion is followed by an increase in water excretion, which can maintain osmotic balance[11]. The results of systolic and diastolic blood pressure can be seen in Tables 1 .

Table 1. Mean of systolic and diastolic blood pressure with the time of each treatment.

I : Negative control (CMC Na 1percent)

II : Positive control (Hidrochlorothiazide)

III : Extract of tali bamboo shoot $40 \mathrm{mg} / \mathrm{KgBB}$
IV : Extract of tali bamboo shoot $80 \mathrm{mg} / \mathrm{KgBB}$

$\mathrm{V}$ : Extract of tali bamboo shoot $160 \mathrm{mg} / \mathrm{KgBB}$

T0 : Baseline blood pressure $(\mathrm{mmHg})$ 
$\mathrm{T} 1$

: Blood pressure on the day 7 after induction with prednisone $1,5 \mathrm{mg} / \mathrm{kg}$ and $\mathrm{NaCl} 150 \mathrm{mg} / \mathrm{kg}$ (mmHg)

$\mathrm{T} 2$ : Blood pressure on the day 14 after induction with prednisone $1,5 \mathrm{mg} / \mathrm{kg}$ and $\mathrm{NaCl} 150 \mathrm{mg} / \mathrm{kg}$ : Blood pressure on the day 21 after induction with prednisone $1,5 \mathrm{mg} / \mathrm{kg}$ dan $\mathrm{NaCl} 150 \mathrm{mg} / \mathrm{kg}$ : Blood pressure on the day 28 after induction and treatment $(\mathrm{mmHg})$

: Blood pressure on the day 35 after induction and treatment $(\mathrm{mmHg})$

: Blood pressure on the day 35 after induction and treatment $(\mathrm{mmHg})$

Tali bamboo shoot extract with a dose of $40 \mathrm{mg} / \mathrm{kg}$, $80 \mathrm{mg} / \mathrm{kg}$, and $160 \mathrm{mg} / \mathrm{kg}$ can provide a systolic blood pressure reduction effect. The difference in systolic blood pressure reduction from all groups can be known by performing one-way ANOVA statistical analysis with a 95percent confidence level. At the end of the study each treatment group had a sig $<0.05$, so there was a significant difference from each group on the reduction in blood pressure. The results of statistical analysis with ShapiroWilk test for initial and final blood loss with sig> 0.05 indicate that the data are normally distributed, so that it is continued with the One-Way ANOVA test. One-Way ANOVA test results showed a significant difference between each treatment group with a significant value at T4 to T6, then continued with parametric tests using the Dunnet T3 Test, at the beginning to the end of the examination the results of systolic blood pressure measurements were obtained in group I (CMC 1 percent) showed a significant difference in group II (Hydrochlorothiazide), group III (/ $2 \mathrm{DE} 40 \mathrm{mg} / \mathrm{kg}$ ), group IV (1 DE $80 \mathrm{mg} / \mathrm{kg}$ ), and group V (2 DE $160 \mathrm{mg} /$ $\mathrm{kg}$ ). An increase in blood pressure is a significant difference between $\mathrm{T} 0$ and $\mathrm{T} 3$, these results are due to statistical tests using the $\mathrm{T}$ test, the result of sig $<0.05$, it can be said that there is a significant difference. The test results show that there are significant differences between each examination time, from $\mathrm{T} 0$ to $\mathrm{T} 6$.

Based on the table above shows that the mean of diastolic blood pressure after induction of prednisone and $\mathrm{NaCl}$ at $\mathrm{T} 1$ to $\mathrm{T} 3$ all groups had an increase in diastolic pressure, then in group I continued to experience an increase in diastolic blood pressure up to T6, this is because the administration of CMC had no effect in decreasing systolic and diastolic blood pressure. In the test group given hydrochlorothiazide drugs as a blood pressure reducer showed that it can reduce blood pressure, and based on the above data a decrease in diastolic blood pressure the group given hydrochlorothiazide drugs from T4 to T6 had a significant decrease[12]. In all test groups that were given tali bamboo shoot extract can reduce diastolic blood pressure from T4 to T6, but the decrease in diastolic blood pressure in the extract group was not as great as the group given hydrochlorothiazide drugs.

In group II there was an increase in diastolic blood pressure at $\mathrm{T} 1$ to $\mathrm{T} 3$ after prednisone and $\mathrm{NaCl}$ were induced, then diastolic blood pressure dropped at $\mathrm{T} 4$ to $\mathrm{T} 6$ after being given therapy. This reduction was greater than in group III, IV, or V because group II was a positive control that is hydrochlorothiazide drug. In group III there was an increase in diastolic blood pressure at $\mathrm{T} 1$ to $\mathrm{T} 3$ after induction of prednisone and $\mathrm{NaCl}$, then blood pressure dropped at $\mathrm{T} 4$ to $\mathrm{T} 6$ after being given therapy, this decrease was smaller than group II. In group IV there was an increase in diastolic blood pressure at $\mathrm{T} 1$ to $\mathrm{T} 3$ after induction of prednisone and $\mathrm{NaCl}$, then blood pressure dropped at $\mathrm{T} 4$ to $\mathrm{T} 6$ after treatment, this reduction was greater than in groups III and V, but the decrease in blood pressure was smaller compared to group II. In group V there was an increase in diastolic blood pressure at $\mathrm{T} 1$ to $\mathrm{T} 3$ after prednisone and $\mathrm{NaCl}$ were induced, then diastolic blood pressure dropped at T4 to T6 after being given therapy, diastolic blood pressure in group $\mathrm{V}$ experienced an increase in diastolic blood pressure very high at $\mathrm{T} 3$, then blood pressure diastole in group V decreases dramatically at $\mathrm{T} 5$ to $\mathrm{T} 6$, this condition is likely influenced by conditions in mice. Based on the results of the average diastolic blood pressure in various groups shows the results of a high standard deviation, this means that the greater the standard deviation indicates the more spread of observational data, and has a tendency for each data to differ from one another.

\section{CONCLUSION}

The content of chemical compounds identified from tali bamboo shoot powder and extracts include saponins, flavonoids, polyphenols and tannins. The content of these chemical compounds make the extract to have antihypertensive activity at doses of $40 \mathrm{mg} / \mathrm{BW}, 80 \mathrm{mg} /$ $\mathrm{BW}$ and $160 \mathrm{mg} / \mathrm{BW}$.

\section{ACKNOWLEDGMENT}

This study conducted based on the funding given by HarapanBangsa University, Indonesia based on the annual research grant year 2018/2019.

\section{REFERENCES}

[1] A. Widiarti, "Pengusahaan Shoot Bambu Oleh Masyarakat, Studi Kasus Di Kabupaten Demak Dan Wonosobo," J. Penelit. Hutan dan Konserv. Alam, vol. 10, no. 1, pp. 51-61, 2013.

[2] I. P. G. P. Damayanto and K. Rahmawati, "Karakteristik Koleksi Spesimen Tipe Bambu Di Herbarium Bogoriense, Pusat Penelitian Biologi Lipi," Baca J. Dokumentasi Dan Inf., vol. 39, no. 2, p. 113, 2018.

[3] N. Chongtham, M. S. Bisht, and S. Haorongbam, "Nutritional Properties of Bamboo Shoots: Potential and Prospects for Utilization as a Health Food," Compr. Rev. Food Sci. Food Saf., vol. 10, no. 3, pp. 153-168, 2011.

[4] P. Nongdam and L. Tikendra, "The Nutritional 
Facts of Bamboo Shoots and Their Usage as Important Traditional Foods of Northeast India," Int. Sch. Res. Not., vol. 2014, pp. 1-17, 2014.

[5] N. Handayani Latuconsina and dan Gayatri Citraningtyas, "UJI EFEKTIVITAS DIURETIK EKSTRAK ETANOL BIJI SALAK (Salacca zalacca varietas zalacca (gaert.) Voss) PADA TIKUS PUTIH JANTAN GALUR WISTAR (Rattus norvegicus)," PHARMACON J. Ilm. Farm. - UNSRAT Agustus, vol. 3, no. 3, pp. 2302-2493, 2014.

[6] E. Kurniawati, "DAYA ANTIBAKTERI EKSTRAK ETANOL TUNAS BAMBU APUS TERHADAP BAKTERI Escherichia coli dan Staphylococcus aureus SECARA IN VITRO," J. Wiyata, vol. 2, no. 2, pp. 193-199, 2015.

[7] M. A. dan N. R. Rahmi, Miftahul, "Jurnal Farmasi dan Kesehatan," Sci. J. Farm. dan Kesehat., vol. 7, no. 2, pp. 134-140, 2017.

[8] R. S. dan R. Supomo Junaid, "( Callicarpa longifolia Lamk . ) CHARACTERIZATION AND LEAVES PHYTOCHEMICAL SCREENING KEREHAU ( Callicarpa longifolia Lamk .)," J. Kim. Mulawarman, vol. 13, 2016.

[9] I. Purwidyaningrum, E. Y. Sukandar, and I. Fidrianny, "Antihypertensive activity of extract and fractions of matoa (Pometia Pinnata J. R \& G forts) leaves," Asian J. Pharm. Clin. Res., vol. 10, no. 3, pp. 323-328, 2017.

[10] E. W. Ulfatun Nisa, Ulfa Fitriani, “Jurnal Kefarmasian Indonesia Aktivitas Ramuan Daun Salam, Herba Pegagan , Akar Alang-Alang dan Biji Pala pada Tikus Hipertensi yang Diinduksi Prednison dan Garam The Activities of Indonesian Bay-Leaves , Centella Herbs , BladyGrass Roots and Nutmeg Seed," J. Kefarmasian Indones., vol. 7, no. 2, pp. 87-94, 2017.

[11] D. R. Sari, L. Mulqie, and S. Hazar, "Uji Efek Diuretik Ekstrak Etanol Herba Ruku-Ruku (Ocimum tenuiflorum L.) terhadap Tikus Wistar Jantan," Pros. Penelit. Spes. Unisba 2015, pp. 159-163, 2015.

[12] O. Jimmy Devi and P. Pamba, "Antihypertensive activity of bamboo shoot: A review," Asian J. Pharm. Clin. Res., vol. 8, no. 1, pp. 46-47, 2015. 